\title{
Efektivitas Pendekatan Matematika Realistik Berbasis Etnomatematika Dalam Meningkatkan Hasil Belajar Peserta Didik Sekolah Dasar
}

\author{
Umar $^{1}$, Arif Widodo ${ }^{2}$, Mohammad Archi Maulyda ${ }^{3}$, Ashar Pajarungi Anar ${ }^{4}$, Deni \\ Sutisna $^{5}$ \\ Prodi Studi PGSD FKIP Universitas Mataram ${ }^{1,2,3,4,5}$ \\ Umarelmubaraq90@unram.ac.id ${ }^{1}$, arifwidodo@unram.ac.id ${ }^{2}$, \\ archimaulyda@unram.ac.id ${ }^{3}$, ashar.pajarungianar@unram.ac.id ${ }^{4}$, \\ denisutisna@unram.ac.id ${ }^{5}$
}

\begin{abstract}
Abstrak
Pelajaran matematika masih menjadi momok bagi peserta didik sekolah dasar. Sifat matematika yang abstrak menyebabkan peserta didik sulit memahami materi dengan baik. Oleh sebab itu, pembelajaran matematika harus dirancang agar lebih dekat dengan kehidupan sehari-hari peserta didik. Tujuan penelitian ini untuk mengetahui efektivitas pendekatan matematika realistik berbasis etnomatematika dalam meningkatkan hasil belajar peserta didik di sekolah dasar. Jenis Penelitian ini adalah penelitian eksperimen. Desain penelitian yang digunakan adalah one shot case study. Populasi dan sampel dalam penelitian ini adalah seluruh peserata didik kelas V MIN 1 Mangagarai sebanyak 37 orang. Teknik pengambilan sampel yang digunakan adalah teknik sampling jenuh. Instrumen penelitian yang digunakan adalah tes hasil belajar. Hasil penelitian menunjukkan bahwa $t_{\text {hitung }}=2.945>t_{\text {tabel }}=1.688$ pada $\alpha=$ 0.05. Berdasarkan kriteria uji $t$ maka dapat disimpulkan bahwa pendekatan matematika realistik berbasis etnomatematika efektif di terapkan pada pembelajaran matematika di kelas V MIN 1 Manggarai.
\end{abstract}

Kata Kunci: Matematika Realistik, Etnomatematika, hasil belajar. 


\section{PENDAHULUAN}

Matematika memiliki karakter yang tidak sama dengan mata pelajaran yang lain, salah satunya adalah memiliki objek kajian yang bersifat abstrak (Maulyda, Umar, et al., 2020). Sifat abstrak ini diyakini sebagai penyebab banyak peserta didik pada jenjang sekolah dasar mengalami kesulitan dalam memahami konsep matematika. Implikasinya adalah rendahnya minat belajar siswa terhadap matematika (Umar, 2018). Hal ini perlu dicermati mengingat matematika mempunyai peran yang penting dalam mengembangkan daya intelektual dan keterampilan berfikir siswa (Nurkhasanah et al., 2019). Terlebih lagi dalam menghadapi tantangan abad 21 keterampilan berpikir berpikir tingkat tinggi sangat dibutuhkan (Widodo et al., 2019). Kemampuan matematis dan kemampuan membangun relasi sosial diera abad 21 merupakan salah satu kemampuan yang harus dimiliki oleh setiap peserta didik (Widodo et al., 2020). Perubahan zaman tidak dapat dipungkiri dan selalu memberikan berbagai dampak terhadap perubahan hidup manusia (Sutisna et al., 2020). Rendahnya minat belajar berdampak buruk pada hasil belajar dan prestasi belajar. Hal ini sesuai dengan pendapat (Kaharuddin, 2019) bahwa salah satu faktor yang mempengaruhi prestasi belajar adalah minat belajar. Prestasi belajar matematika peserta didik baik secara nasional maupun internasional masih belum memuaskan (Maulyda, Sukoriyanto, et al., 2020). Third international Mathematics and science study (TIMSS) mengungkapkan bahwa rata-rata skor matematika peserta didik di Indonesia sangat jauh di bawah rata-rata skor peserta didik internasioanal, dan Indonesia berada pada peringkat 34 dari 38 negara (TIMSS, 1999). Prestasi belajar matematika peserta didik yang rendah bisa disebabkan karena belajar matematika peserta didik belum bermakna, sehingga pemahaman peserta didik tentang konsep dalam matematika sangat lemah.

Guru dalam mengajarkan matematika di sekolah sekolah dasar sering tidak mengaitkan atau menghubungkan dengan skema yang telah dimiliki peserta didik. Selain itu peserta didik juga jarang diberikan kesempatan untuk menemukan kembali secara mandiri dan mengkontruksi sendiri ide-ide dalam matematika. Piaget dalam (Dahar, 2010) menjelaskan bahwa perkembangan kognitif anak umur 7 tahun sampai 11 tahun atau setara peserta didik pada jenjang sekolah dasar berada pada kategori operasional kongkrit. Oleh karena itu, agar pelajaran matematika mudah dipahami 
oleh peserta didik sekolah dasar, pembelajaran di sekolah harus dikaitkan dengan lingkungan sekitar. Sejalan dengan itu (Soejadi, 2000) mengatakan bahwa menghubungkan pengalaman dalam kehidupan nyata peserta didik dengan ide-ide matematika dalam proses belajar mengajar di kelas sangat penting untuk dilakukan agar proses belajar mengajar menjadi lebih bermakna. Menghubungkan pembelajaran matematika di kelas dengan pengalaman nyata dapat membantu peserta didik mengaplikasikan matematika dalam kehidupan sehari-hari, dan peserta didik tidak cepat lupa dengan materi matematika. Menurut pendapat (Murwatiningsih et al., 2019) dalam menghadapi tantangan global hendaknya menggunakan modelmodel pembelajaran yang baru. Inovasi pembelajaran penting untuk dilakukan, mengingat cara-cara pembelajaran lama yang cenderung mekanistik membuat peserta didik pasif sehingga kreativitas berfikir kurang berkembang (Wahyudi, 2012). Terlebih lagi dalam memfasilitasi pengembangan keterampilan abad 21 pendekatan pembelajaran harus diperbaharui. Hal ini bertujuan agar konsep matematika yang sulit dapat dengan mudah dipahami oleh peserta didik. Salah satu pendekatan dalam pembelajaran matematika yang mengaitkan konsep matematika dengan pengalaman nyata peserta didik adalah pendekatan matematika realistik berbasis etnomatematika.

Pendekatan matematika realistik pertama kali dikembangkan oleh ilmuwan asal belanda yaitu Hans Freudental. Pendekatan ini didasarkan pada pemikiran Freudental yang mengatakan bahwa matematika merupakan aktivitas manusia (human activities) (Wijaya, 2012). Ide utamanya adalah peserta didik harus diberi kesempatan dan kebebasan untuk menemukan kembali ide serta konsep matematika secara mandiri tanpa arahan atau bimbingan guru. Upaya ini bisa dilakukan dengan cara menjelajahi berbagai situasi atau persoalan-persoalan realistik yakni persoalan yang berhubungan dengan realitas atau situasi yang bisa dibayangkan oleh peserta didik. Salah satu kelebihan penerapan pendekatan matematika realistik dalam pembelajaran matematika adalah membimbing peserta didik untuk mencari dan menemukan hal-hal nyata dan kongkrit (Tim MKPBM UPI, 2001). Beberapa karakteristik pendekatan matematika realistik menurut (Treffers, 1991) yaitu: (1) menggunakan persoalan atau masalah realistik atau yang berkaitan dengan dunia nyata peserta didik; (2) menggunakan model. (3) menggunakan kontribusi atau 
kontruksi peserta didik; (4) ada interaksi saat proses belajar mengajar; (5) menggunakan teori belajar yang sesuai atau relevan; (6) terintegrasi dengan materi pembelajaran lainnya. Pendekatan matematika realistik merupakan salah satu pendekatan dalam pembelajaran matematika yang sesuai dengan teori belajar yang sedang berkembang saat ini, yaitu konstruktivisme. Berdasarkan uraian di atas, pembelajaran matematika harus menekankan pada hubungan antara konsep-konsep dalam matematika dengan pengalaman sehari-hari peserta didik.

Etnomatematika dapat diartikan sebagai konsep atau unsur matematika yang dipraktekkan oleh kelompok masyarakat atau kelompok budaya dalam kehidupan sehari-hari (D’Ambrosio, 1985). Pembelajaran berbasis etnomatematika dapat dilakukan oleh guru dengan menggunakan budaya disekitar peserta didik sebagai alat, media, maupun sumber belajar. Pada dasarnya banyak benda-benda hasil produk budaya yang dapat dikaitkan ke dalam konsep pembelajaran matematika (Fauzi \& Lu'luilmaknun, 2019). Sejalan dengan itu, pendekatan matematika realistik juga menekankan pada kebiasaan serta realitas kehidupan sehari-hari peserta didik. Dengan demikian pendekatan matematika realistik berbasis etnomatematika merupakan pembelajaran yang mengaitkan kebiasaan atau kebudayaan yang ada di sekitar lingkungan peserta didik dengan konsep matematika di sekolah. Pendekatan matematika realistik berbasis etnomatematika merupakan integrasi matematika dan budaya. Oleh karena itu maka guru dalam mengajarkan konsep matematika di sekolah selalu dikaitkan dengan budaya lokal. Hal ini memberi dampak kepada peserta didik dalam memahami manfaat matematika dalam kehidupan sehari-hari. sehingga harapannya adalah agar pembelajaran matematika di sekolah semakin mudah dipahami serta diterapkan oleh peserta didik.

Beberapa hasil penelitian menunjukan bahwa mengaitkan pengalaman nyata peserta didik dalam pembelajaran matematika melalui pendekatan matematika realistik berdampak positif terhadap peningkatan pemahaman konsep peserta didik. Penelitian (Rangkuti, 2015) menunjukkan bahwa penggunaan pendekatan matematika realistik dalam pembelajaran matematika di sekolah dasar dapat memberi kesempatan peserta didik untuk meningkatakan kemampuannya. Penelitian serupa juga telah dilakukan (Zaini \& Marsigit, 2014) dengan subjek salah satu sekolah di Kota Banjarmasin. Hasil penelitian tersebut menyimpulkan bahwa 
pembelajaran matematika dengan penerapan pendekatan matematika realistik jauh lebih baik dalam meningkatkan penalaran matematika peserta didik dibandingkan pembelajaran konvensional. Lebih lanjut hasil Penelitian yang dilakukan oleh (S. Sirate, 2012) bahwa penerapan etnomatematika dalam pembelajaran matematika dapat meningkatkan motivasi serta mengurangi kejenuhan peserta didik sekolah dasar. Dari uraian di atas maka peneliti tertarik untuk melakukan penelitian tentang efektivitas pendekatan matematika realistik berbasis etnomatematika dalam meningkatkan hasil belajar pada peserta didik sekolah dasar.

\section{METODE PENELITIAN}

Tujuan penelitian ini untuk mengetahui efektivitas pendekatan matematika realistik berbasis etnomatematika dalam pembelajaran matematika untuk meningkatkan hasil belajar peserta didik. Populasi dan sampel penelitian ini adalah seluruh siswa kelas V MIN 1 Manggarai. Teknik pengambilan sampel yang digunakan adalah teknik sampling jenuh. Instrumen penelitian yang digunakan adalah tes hasil belajar. Jenis penelitian ini adalah jenis penelitian eksperimen, yaitu metode penelitian yang digunakan untuk mencari hubungan variabel tertentu terhadap variabel yang lain dalam kondisi yang terkontrol secara ketat (Sugiyono, 2006). Dalam penelitian ini melibatkan kelompok tunggal dan tidak ada perbandingan dengan kelompok non perlakuan. Desain penelitian yang digunakan adalah one shot case study. Penggunaan desain penelitian ini karena ukuran populasi yang relatif sedikit yaitu hanya satu kelas. Dengan demikian dalam penelitian ini tidak ada kelas kontrol. Adapun skema penelitian menurut (Lestari \& Yudhanegara, 2015) adalah sebagai berikut:

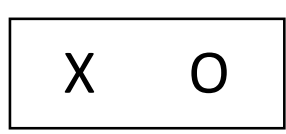

Gambar 1. The one shot case study Design

Keterangan :

$\mathrm{X}$ : perlakuan (Treatment)

$\mathrm{O}$ : Post test, yaitu tes hasil belajar matematika peserta didik setelah menerapkan pendekatan matematika realistik berbasis etnomatematika . 
Prosedur penelitian dimulai dengan memberikan perlakuan (treatment) kepada satu kelompok peserta didik peserta didik melalui penerapan pendekatan matematika reaalistik berbasis etnomatematika dalam pembelajaran matematika. Selama jangka waktu tertentu perlakuan (treatment) dihentikan, dan peserta didik diberikan soal post test untuk mengukur hasil belajar peserta didik. Perlakuan (treatment) merupakan variabel independen, dan hasil belajar merupakan variabel dependen. Untuk mengukur apakah pendekatan matematika realistik berbasis etnomatematika efektif meningkatkan hasil belajar matematika, Peneliti menganalisis data post test hasil belajar peserta didik menggunakan analisis statistik deskriptif dan analisis statistik inferensial.

\section{HASIL DAN PEMBAHASAN}

\section{Hasil Analisis Statistik Deskriptif}

Data hasil belajar matematika peserta didik dengan penerapan pendekatan matematika realistik berbasis etnomatematika diperoleh dari hasil post test. Data tersebut dianalisis secara deskriptif untuk melihat distribusi dan presentase hasil belajar peserta didik. Jika skor tes hasil belajar matematika peserta didik yang diajar dengan pendekatan matematika realistik berbasis etnomatematika dikelompokkan ke dalam lima kategori, maka diperoleh distribusi skor frekuensi dan persentase yang ditunjukkan pada Tabel 2. sebagai berikut:

Tabel 1. Distribusi dan persentase skor tes hasil belajar matematika peserta didik setelah penerapan pendekatan matematika realistik berbasis etnomatematika (Posttest)

\begin{tabular}{ccccc} 
NO & Skor & Kategori & Frekuensi & Presentase \% \\
\hline 1 & $0 \leq \times \leq 54$ & Sangat Rendah & 3 & 5 \\
\hline 2 & $54<\times \leq 69$ & Rendah & 2 & 8 \\
\hline 3 & $69<\times \leq 79$ & Sedang & 11 & 30 \\
\hline 4 & $79<\times \leq 89$ & Tinggi & 16 & 43 \\
\hline 5 & $89<\times \leq 100$ & Sangat Tinggi & 5 & 14 \\
\hline & Jumlah & & 37 & 100
\end{tabular}


Berdasarkan tabel di atas, dapat digambarkan bahwa hasil belajar peserta didik setelah diterapkan pendekatan matematika realistik berbasis etnomatematika yaitu terdapat 5 dari 38 orang peserta didik yang mendapatkan nilai pada kategori rendah dan sangat rendah, jumlah ini masih dianggap sedikit jika dibandingkan dengan jumlah peserta didik memiliki hasil belajar mencapai kategori sedang, tinggi, dan sangat tinggi yaitu 32 dari 38 peserta didik. Selain itu, dari tabel di atas terlihat bahwa secara umum hasil belajar peserta didik berada pada kategori tinggi dengan presentase $43 \%$, dan kategori tinggi merupakan presentase terbesar dari hasil post test peserta didik. Hal ini menunjukan bahwa secara deskriptif penerepan pendekatan matematika realistik berbasis etnomatematika dalam pembelajaran matematika efektif dalam meningkatkan hasil belajar peserta didik.

\section{Hasil Analisis Statistik Inferensial}

Setelah dilakukan uji prasyarat analisis, diperoleh bahwa data hasil post test tersebut berdistribusi normal. Sehingga uji hipotesis yang digunakan adalah uji $t$ yang dirumuskan:

$$
t_{\text {hitung }}=\frac{\bar{X}-\mu_{0}}{\frac{s}{\sqrt{n}}}
$$

Keterangan:

$\bar{X} \quad=$ Rata-rata sampel

$\mu_{0} \quad=$ Nilai KKM mata pelajaran matematika di sekolah

$s \quad=$ Simpangan baku sampel

$\mathrm{n} \quad=$ Banyaknya data

Hasil perhitungan di ketahui bahwa $t_{\text {hitung }}=2.945>t_{\text {tabel }}=1.688$ pada $\alpha=0.05$. Berdasarkan kriteria uji $t$ dapat disimpulkan bahwa pendekatan matematika realistik berbasis etnomatematika efektif meningkatkan hasil belajar peserta didik MIN 1 Manggarai. Hasil penelitian ini selaras dengan hasil penelitian yang dilakukan (Rangkuti, 2015), bahwa pendekatan matematika realistik dapat meningkatkan pemahaman konsep matematika peserta didik. Selain itu hasil juga selaras dengan hasil penelitian yang dilakukan oleh (Zaini \& Marsigit, 2014) yaitu pembelajaran matematika dengan penerapan pendekatan matematika realistik jauh lebih baik dalam meningkatkan penalaran matematika peserta didik dibandingkan pembelajaran 
konvensional. Pemahaman konsep dan kemampuan penalaran matematika yang baik, dapat memudahkan peserta didik dalam menyelesaiakan soal-soal matematika sehingga berdampak positif terhadap peningkatan hasil belajar dan prestasi belajar peserta didik. Pendekatan matematika realistik merupakan salah satu pendekatan berbasis teori belajar kontruktivis, sehingga peserta didik lebih aktif untuk mengembangkan sendiri pengetahuannya baik secara personal maupun kelompok belajar. Keaktifan peserta didik dalam berpikir, bernalar, dan mengkontruksi sendiri pengetahuannya secara terus menerus dapat meningkatkan hasil belajar.

Penerapan pendekatan matematika realistik berbasis etnomatematika dalam pembelajaran matematika di sekolah dasar membimbing peserta didik memahami makna dan konsep materi yang sedang dipelajari dengan baik. Hal ini terjadi karena dalam pembelajaran guru berusaha menghubungkan pengalaman, kebiasaan, peserta didik serta budaya yang ada di lingkungan sekitar dengan materi yang sedang dipelajari. Hal ini sesuai dengan pernyataan (Fauzi et al., 2020) bahwa pembelajaran yang mengaitkan dengan kehidupan peserta didik akan lebih bermakna. Selain itu, dengan mengaitkan materi pelajaran dengan situasi kehidupan nyata serta budaya di lingkungan sekitar membuat peserta didik memahami manfaat belajar. Menurut (Umar et al., 2020) kebanyakan peserta didik tidak mengerti manfaat mempelajari matematika di sekolah. Ini ditandai dengan banyak peserta didik yang tidak mengetahui bagaimana penerapan konsep matematika yang dipelajari di sekolah ke dalam kehidupan nyata. sehubungan dengan itu, penerapan pendekatan matematika realistik berbasis etnomatematika sejatinya mampu menjawab persoalan itu. Hal ini karena pendekatan matematika realistik berbasis etnomatematika merupakan integrasi matematika dan budaya. Oleh karena itu maka guru dalam mengajarkan konsep matematika di sekolah selalu mengaitkannya dengan budaya lokal (Fauzi \& Lu'luilmaknun, 2019). Sehingga peserta didik menyadari bahwa apa yang akan dipelajari memberi makna serta manfaat bagi kehidupannya nanti. Pemahaman terhadap makna dan manfaat belajar dapat memicu semangat serta motivasi peserta didik untuk berusaha memahami materi yang sedang dipelajari. Oleh sebab itu maka pembelajaran matematika di sekolah semakin mudah dipahami serta diterapkan oleh peserta didik. 


\section{KESIMPULAN}

Berdasarkan hasil penelitian dan pembahasan dapat disimpulkan bahwa pendekatan matematika realistik berbasis etnomatematika dapat meningkatkan hasil belajar matematika peserta didik. Hal ini dapat diartikan bahwa pendekatan matematika realistik berbasis etnomatematika efektif diterapkan dalam pembelajaran matematika pada jenjang sekolah dasar di Kabupaten Manggarai.

\section{DAFTAR PUSTAKA}

D'Ambrosio, U. (1985). Ethnomathematics and its Place in the History and Pedagogy of Mathematics. For the Learning of Mathematics - An International Journal of Mathematics Education, 5(1), 44-48.

Dahar, R. W. (2010). Teori-teori belajar dan pembelajaran. Erlangga.

Fauzi, A., \& Lu'luilmaknun, U. (2019). Etnomatematika pada permainan dengklaq sebagai media pembelajaran matematika. AKSIOMA: Jurnal Program Studi Pendidikan Matematika, 8(3), 408. https://doi.org/10.24127/ajpm.v8i3.2303

Fauzi, A., Widjajanti, D. B., Widodo, A., \& Umar, U. (2020). Developing the Set of Mathematics Learning Materials Based on NHT Model With Peer Assessment. Atlantis Press, 465(Access 2019), 90-93. https://doi.org/10.2991/assehr.k.200827.024

Kaharuddin, A. (2019). Effect of Problem Based Learning Model on Mathematical Learning Outcomes of 6th Grade Students of Elementary School Accredited B in Kendari City. International Journal of Trends in Mathematics Education Research, 1(2), 43-46. https://doi.org/10.33122/ijtmer.v1i2.14

Lestari, K. E., \& Yudhanegara, M. R. (2015). Penelitian pendidikan matematika (Anna (ed.); 1st ed.). PT Refika Aditama.

Maulyda, M. A., Sukoriyanto, S., Hidayati, V. R., Erfan, M., \& Umar, U. (2020). Student Representation in Solving Story Problems Using Polya Steps. Formatif: Jurnal Ilmiah Pendidikan MIPA, 10(1), 25-34. https://doi.org/10.30998/formatif.v10i1.4629

Maulyda, M. A., Umar, Erfan, M., Hidayati, V. R., \& Haryati, L. F. (2020). IMPLEMENTATION OF STAD TYPE COOPERATIVE LEARNING TO IMPROVE MATHEMATICAL LEARNING OUTCOMES CLASS VIII STUDENTS. Jurnal Ilmiah Pendidikan Matematika, 5(1), 1-12.

Murwatiningsih, E., Wahyudi, W., \& Setiawan, Y. (2019). EFEKTIVITAS MODEL THINK TALK WRITE DAN THINK PAIR SHARE TERHADAP PENINGKATAN KEMAMPUAN KOMUNIKASI MATEMATIS SISWA KELAS 4 SD. Satya Widya, 35(1), 42-53. https://doi.org/10.24246/j.sw.2019.v35.i1.p42-53

Nurkhasanah, D., Wahyudi, W., \& Indarini, E. (2019). PENERAPAN MODEL PROBLEM BASED LEARNING UNTUK MENINGKATKAN KEMAMPUAN BERPIKIR KRITIS SISWA KELAS V SD. Satya Widya, 35(1), 33-41. https://doi.org/10.24246/j.sw.2019.v35.i1.p33-41 
Rangkuti, A. N. (2015). Developing a Learning Trajectory on Fraction Topics by Using Realistic Mathematics Education Approach In Primary School. IOSR Journal of Research \& Method in Education Ver. III, 5(5), 2320-7388. https://doi.org/10.9790/7388-05531316

S. Sirate, F. (2012). Implementasi Etnomatematika Dalam Pembelajaran Matematika Pada Jenjang Pendidikan Sekolah Dasar. Lentera Pendidikan: Jurnal Ilmu Tarbiyah Dan Keguruan, 15(1), 41-54. https://doi.org/10.24252/lp.2012v15n1a4

Soejadi. (2000). Nuansa Kurikulum Matematika Sekolah Di Indonesia”. Dalam Majalah Ilmiah Himpunan Matematika Indonesia (Prosiding Konferensi Nasional Matematika XITB, !7-20 Juli 2000).

Sugiyono. (2006). Metode penelitian kuantitatif kualitatif dan R\&D. Alfa Beta.

Sutisna, D., Widodo, A., Nursaptini, N., Umar, U., Sobri, M., \& Indraswati, D. (2020). An Analysis of the Use of Smartphone in Students' Interaction at Senior High School. Atlantis Press, 465(Access 2019), 221-224. https://doi.org/10.2991/assehr.k.200827.055

Tim MKPBM UPI. (2001). Common Teks Book Strategi Pembelajaran Matematika Kontemporer. Jica Uneversitas Pendidikan Indonesia (UPI).

TIMSS. (1999). International Student Achievement in Mathematics. http://timss.bc.edu/ timss1999i/pdf/T99i math 01.pdf

Treffers. (1991). Realistic Mathematics Education in the Netherlands 1980-1990. In L. Streefland (Ed.). Realistic Mathematics Education in Primary School. CD-B Press, Freudenthal Institute.

Umar. (2018). The effectiveness of cooperative learning model of stad thype based on gagne learning theory in mathematics learning class vii at MTs with $\mathrm{b}$ accreditation in Makassar city. DAYA MATEMATIS: Jurnal Inovasi Pendidikan Matematika, 7(2), 219-227.

Umar, U., Kaharuddin, A., Fauzi, A., Widodo, A., Radiusman, R., \& Erfan, M. (2020). A Comparative Study on Critical Thinking of Mathematical Problem Solving Using Problem Based Learning and Direct Intruction. 465(Access 2019), 314-316. https://doi.org/10.2991/assehr.k.200827.079

Wahyudi, W. (2012). PENGEMBANGAN BAHAN AJAR ELEKTRONIK MULTIMEDIA DENGAN MACROMEDIA FLASH 8.0 UNTUK MAHASISWA S1 PGSD UKSW. Satya Widya, 28(1), 55. https://doi.org/10.24246/j.sw.2012.v28.i1.p55-72

Widodo, A., Indraswati, D., Radiusman, R., Umar, U., \& Nursaptini, N. (2019). Analisis Konten HOTS dalam Buku Siswa Kelas V Tema 6 "Panas dan Perpindahannya " Kurikulum 2013. Madrasah: Jurnal Pendidikan Dan Pembelajaran Dasar, 12(1), 113. https://doi.org/http://dx.doi.org/10.18860/mad.v12i1.7744

Widodo, A., Maulyda, M. A., Fauzi, A., Sutisna, D., Nursaptini, N., \& Umar, U. (2020). Tolerance Education Among Religious Community Based on the Local Wisdom Values in Primary Schools. Atlantis Press, 465(Access 2019), 327-330. https://doi.org/10.2991/assehr.k.200827.082 
Wijaya, A. (2012). Pendidikan matematika realistik: suatu alternatif pendekatan pembelajaran matematika (1st ed.). Graha Ilmu.

Zaini, A., \& Marsigit. (2014). Perbandingan keefektifan pembelajaran matematika dengan pendekatan matematika realistik dan konvensional ditinjau dari kemampuan penalaran dan komunikasi matematik siswa. Jurnal Riset Pendidikan Matematika, 1(1), 48-57. 